\title{
Transformation of Nitrite and Nitric Oxide Produced by Oral Bacteria to Reactive Nitrogen Oxide Species in the Oral Cavity
}

\author{
Umeo Takahama ${ }^{1}$ and Sachiko Hirota ${ }^{2}$ \\ ${ }^{1}$ Kyushu Dental College, Kitakyushu, \\ ${ }^{2}$ Kyushu Women's University, Kitakyushu \\ Japan
}

\section{Introduction}

Nitrate and nitrite are present in the human oral cavity. The main origin of these components is nitrate that is contained in leafy vegetables such as lettuce and spinach (Tamme et al., 2006). Ingested nitrate is absorbed into human body by the intestine, and part of the absorbed nitrate is secreted into the oral cavity as a component of saliva. In the oral cavity, nitrate is reduced to nitrite by nitrate-reducing bacteria (Doel et al., 2004, 2005; Zetterquist et al., 1999), and nitrite is reduced to nitric oxide (NO) by nitrite-reducing bacteria (Palmerini et al., 2003). If NO is produced from nitrite by nitrite-reducing bacteria, $\mathrm{NO}$ can autoxidize to dinitrogen trioxide $\left(\mathrm{N}_{2} \mathrm{O}_{3}\right)$ and can react with superoxide anion radical $\left(\mathrm{O}_{2}{ }^{-}\right)$to produce a strong oxidant peroxynitrite $\left(\mathrm{ONOO}^{-} / \mathrm{ONOOH}, \mathrm{pKa}=6.8\right)$ $\left(\mathrm{ONOOH} / \mathrm{NO}_{2}, \mathrm{E}^{\mathrm{O} \prime}=2.10 \mathrm{~V}\right.$ at $\mathrm{pH}$ 7) (Halliwell \& Gutteridge, 1999). In the oral cavity, two peroxidases are present; one is salivary peroxidase that is derived from saliva and the other is myeloperoxidase that is derived from leukocytes migrated into the oral cavity. Nitrite can be oxidized by these peroxidases producing nitrogen dioxide $\left(\mathrm{NO}_{2}\right)$ (van der Vliet et al., 1997). The $\mathrm{E}^{\mathrm{o}}$ of $\mathrm{NO}_{2} / \mathrm{NO}_{2}{ }^{-}$at $\mathrm{pH} 7$ is $0.99 \mathrm{~V}$ (Halliwell \& Gutteridge, 1999). If the $\mathrm{pH}$ in the oral cavity decreased around 5 , nitrite ion is protonated to produce nitrous acid ( $\mathrm{pKa}=3.3$ ) that can be transformed to $\mathrm{NO}, \mathrm{N}_{2} \mathrm{O}_{3}, \mathrm{NO}_{2}$, and $\mathrm{NO}^{+}\left(\mathrm{NO}^{+} / \mathrm{NO}, \mathrm{E}^{\mathrm{o}}=1.21 \mathrm{~V}\right.$ at $\mathrm{pH}$ 7) by selfdecomposition (Oldrreive \& Rice-Evabs, 2001). In this way, the formation of nitrite and NO by oral bacteria results in the production of reactive nitrogen oxide species (RNOS) by various reactions. This chapter deals with the mechanisms of production of RNOS in the human oral cavity under neutral and acidic conditions. Taking the mechanism into consideration, we discuss that the decrease in $\mathrm{pH}$ in the oral cavity results in the injury of oral tissue cells.

\section{Measurements of RNOS}

Production of RNOS in the oral cavity can be measured by (1) trapping of NO with Fe- $\mathrm{N}$ (dithiocarboxy)sarcosine [Fe(DTCS $\left.)_{3}\right]$ complex, (2) transformation of 4,5diaminofluorescein (DAF-2) and 3-amino-4-monomethylamino-2', $7^{\prime}$-difluorofluorescein 
(DAF-FM) to their triazole forms, (3) oxidative degradation of aminophenyl fluorescein (APF) to fluorescein, (4) nitration of 4-hydroxyphenyl acetic acid (HPA), and (5) oxidation of uric acid.

Two preparations obtained from mixed whole saliva are use to study the formation RNOS in the oral cavity. One is saliva filtrate prepared by filtration of mixed whole saliva through two layers of nylon filter net, and the other is bacterial fraction prepared by centrifugation of the saliva filtrate.

\subsection{NO-trapping}

$\mathrm{Fe}(\mathrm{DTCS})_{3}$ is prepared by addition of $0.03 \mathrm{~mL}$ of $100 \mathrm{mM} \mathrm{FeCl}_{3}$ to $1 \mathrm{~mL}$ of $10 \mathrm{mM}$ DTCS in $50 \mathrm{mM}$ sodium phosphate (pH 7-7.6) (Fujii et al., 1996). The Fe(DTCS) ${ }_{3}$ solution $(0.2 \mathrm{~mL}$ ) is added to $0.2 \mathrm{~mL}$ of saliva filtrate or bacterial fraction (Takahama et al., 2008a). Fe(DTCS) $)_{3}$ is transformed to $\mathrm{NO}-\mathrm{Fe}(\mathrm{DTCS})_{2}$ after tapping NO. The formation of $\mathrm{NO}-\mathrm{Fe}(\mathrm{DTCS})_{2}$ was measured using an electron spin resonance (ESR) spectrometer with a quartz flat cell (0.05 $\mathrm{mL})$. ESR spectra were recorded at room temperature under the following conditions: microwave power, $10 \mathrm{~mW}$; scanning speed, $5 \mathrm{mT} / \mathrm{min}$; line width, $0.5 \mathrm{mT}$; and amplification, 1000- or 2000-fold depending on ESR signal intensity.

\subsection{Transformation of fluorescein derivatives to their triazole forms}

DAF-2 and DAF-FM are used to detect the formation of NO under aerobic conditions. The fluorescent yields of these components increase significantly after the transformation to the triazole forms, namely, DAF-2T and DAF-FMT (Kojima et al., 1998, 1999). The excitation wavelengths (495 and $500 \mathrm{~nm}$ for DAF-2T and DAF-FMT, respectively) and the emission wavelengths (515 nm for DAF-2T and DAF-FMT) make easy to use these compounds because saliva filtrate and bacterial fraction don't absorb light around $500 \mathrm{~nm}$. The formation of DAF-2T and DAF-FMT can be ascertained by HPLC (Takahama et al., 2005; 2009a).

In addition to the above fluorescent probes, APF is used to detect strong oxidants such as $\mathrm{OH}$ radical $\left(\mathrm{OH}\right.$ radical $/ \mathrm{OH}^{-}, \mathrm{E}^{\mathrm{o} \prime}=2.31 \mathrm{~V}$ at $\left.\mathrm{pH} 7\right), \mathrm{NO}_{2}, \mathrm{ONOOH}$, and $\mathrm{HOCl}$ but not $\mathrm{O}_{2}^{-}$ (Setsukinai et al., 2003). Because one of the oxidation products is fluorescein, the oxidation of APF can be measured fluorometically. Excitation and emission wavelengths are 490 and $515 \mathrm{~nm}$, respectively. The formation of fluorescein can be ascertained by HPLC (Takahama et al., 2007a).

\subsection{Nitration of HPA}

HPA and tyrosine are used to detect $\mathrm{NO}_{2}$ and $\mathrm{ONOOH}$. HPA, which is produced during tyrosine metabolism by Porphyromonas gingivalis, is present in the mixed whole saliva (Takahama et al, 2002) and is mainly nitrated by peroxidase $/ \mathrm{H}_{2} \mathrm{O}_{2} /$ nitrite systems (Hirota et al., 2005; Takahama et al., 2003a, 2009b). Its nitration product is 4-hydroxy-3nitrophenylacetic acid $\left(\mathrm{O}_{2} \mathrm{NHPA}\right)$. This compound has absorption peaks at about 280 and $360 \mathrm{~nm}$, and can be separated from HPA by HPLC (Takahama et al., 2002).

\subsection{Oxidation of uric acid}

Uric acid, which is present in saliva in the concentration range from 80 to $280 \mu \mathrm{M}$ (Ferguson, 1989), is an important antioxidant, and this component can be oxidized by $\mathrm{NO}_{2}$ and 
ONOOH (Halliwell \& Gutteridge, 1999). The oxidation of uric acid is estimated from the absorbance decrease at $284 \mathrm{~nm}$ and the decrease in its concentration by HPLC (Takahama \& Hirota, 2010).

\section{RNOS production}

Around $\mathrm{pH} 7$, RNOS are generated by the autoxidation of NO that is produced by nitritereducing bacteria and by the peroxidase-catalyzed oxidation of nitrite. In addition to the above reactions, RNOS is generated by the self-decomposition of nitrous acid and by the reaction of nitrous acid with a salivary component $\mathrm{SCN}^{-}$under acidic conditions $(\mathrm{pH} \leqq$ 5.3). The followings deal with the formation of RNOS including NO in bacterial fraction and saliva filtrate.

\subsection{Measurement of NO production using $\mathrm{Fe}(\mathrm{DTCS})_{3}$ 3.1.1 NO production around $\mathrm{pH} 7$}

The formation of NO-Fe(DTCS $)_{2}$ is not observed in bacterial fraction, but observed when nitrite is added to bacterial fraction (Takahama et al., 2005; Takahama et al., 2007a). The nitrite-induced NO production supports the reduction of nitrite to NO by nitrite-reducing bacteria (Palmerini et al., 2003). Nitrite concentration in the oral cavity increases after the ingestion of nitrate-containing foods (Pannala et al., 2003). The increase in concentration results in the enhanced production of NO that autoxidizes as followings,

$$
4 \mathrm{NO}+\mathrm{O}_{2} \rightarrow 2 \mathrm{~N}_{2} \mathrm{O}_{3}
$$

Although NO can inhibit bacterial growth (Benjamin et al., 1994; Dykhuizen et al., 1996; Doel et al., 2004), the increased formation of $\mathrm{N}_{2} \mathrm{O}_{3}$ may contribute to give nitrosative stresses to tissues in the oral cavity.

\subsubsection{Enhancement of NO production by decreasing $\mathrm{pH}$}

The $\mathrm{pH}$ in the oral cavity, especially dental plaque, rapidly decreases to below 5 after the ingestion of sugar-containing foods (Marsh \& Martin, 1999; Lingström et al., 2000). The decrease in $\mathrm{pH}$ is due to the production of acid, especially lactic acid and the decreased $\mathrm{pH}$ returns slowly to its preingestion value. The frequency of this $\mathrm{pH}$ decrease depends on the frequency of ingestion of sugar-containing foods. Frequent and prolonged decrease in plaque $\mathrm{pH}$ results in the growth of acid-tolerant bacteria. Nitrite-induced NO production was about 5-fold faster around $\mathrm{pH} 5$ than 7 in bacterial fraction, suggesting the faster production of NO by nitrite-reducing bacteria under acidic conditions (Takahama et al., 2007a, 2009a). In addition to NO production by nitrite-reducing bacteria, self-decomposition of nitrous acid is also possible for NO production under acidic conditions (Oldreive \& RiceEvans, 2001),

$$
\begin{gathered}
\mathrm{NO}_{2}^{-}+\mathrm{H}^{+} \rightleftarrows \mathrm{HNO}_{2}(\mathrm{pKa}=3.3) \\
\mathrm{HNO}_{2}+\mathrm{H}^{+} \rightleftarrows \mathrm{H}_{2} \mathrm{NO}_{2}{ }^{+} \rightleftarrows \mathrm{H}_{2} \mathrm{O}+\mathrm{NO}^{+} \\
2 \mathrm{HNO}_{2} \rightleftarrows \mathrm{N}_{2} \mathrm{O}_{3}+\mathrm{H}_{2} \mathrm{O}
\end{gathered}
$$




$$
\mathrm{N}_{2} \mathrm{O}_{3} \rightleftarrows \mathrm{NO}+\mathrm{NO}_{2}
$$

At $\mathrm{pH} 5$, about $2 \%$ of nitrite is present as nitrous acid.

\subsection{Measurements of RNOS production by fluorescent probes}

DAF-2 and DAF-FM can be used to detect $\mathrm{NO}$ when $\mathrm{pH}$ is higher than 7 and 5, respectively (Kojima et al., 1998, 1999). Because $\mathrm{NO}$ is transformed to $\mathrm{N}_{2} \mathrm{O}_{3}$ under aerobic conditions (reaction 1), $\mathrm{N}_{2} \mathrm{O}_{3}$ or $\mathrm{NO}^{+}$donor can transform of DAF-2 and DAF-FM to DAF-2T (pKa = 6.27) and DAF-FMT (pKa $=4.38$ ), respectively. On the other hand, radicals of DAF-2 and DAF-FM formed by $\mathrm{NO}_{2}$ - and $\mathrm{ONOOH}$-dependent oxidation and peroxidase-catalyzed oxidation can react with NO to produce their triazole forms (Espey et al., 2002; Jourd'heuil, 2002). The above mechanisms of triazole formation suggest that the formation of DAF-2T and DAF-FMT increases with the increase in the concentrations of both NO and oxidants.

\subsubsection{RNOS production around $\mathrm{pH} 7$}

DAF-2T formation in bacterial fraction is dependent on the concentration of nitrite, suggesting the contribution of $\mathrm{NO}$ produced by nitrite-reducing bacteria to DAF-2T formation (Takahama et al., 2005). Ascorbic acid, glutathione, uric acid, $\mathrm{SCN}^{-}$, and phenolic compounds such as quercetin suppresses its formation (Takahama et al., 2006a). The suppression by ascorbic acid, glutathione, uric acid, and phenolic compounds can be attributed to the scavenging of $\mathrm{NO}^{+}, \mathrm{NO}_{2}$, and $\mathrm{ONOOH}$, if these RNOS are contributed to the formation of DAF-2 radical and/or DAF-2T. If the DAF-2 radicals are scavenged by ascorbic acid and other antioxidants, DAF-2T formation is also suppressed. Furthermore, the above antioxidants can inhibit peroxidase-catalyzed oxidation of nitrite and DAF-2 to $\mathrm{NO}_{2}$ and DAF-2 radicals, respectively, to suppress the formation of DAF-2T radical. $\mathrm{SCN}^{-}$is a substrate of salivary peroxidase and myeloperoxidase around $\mathrm{pH} 7$ (Pruitt et al., 1988; Tenovuo, 1989). Therefore, the inhibition of DAF-2T formation by $\mathrm{SCN}^{-}$can be attributed to the suppression of the formation of $\mathrm{NO}_{2}$ and DAF-2 radicals by peroxidases. Oxidation of nitrite by peroxidases proceeds as followings,

$$
\begin{gathered}
\text { Peroxidase }+\mathrm{H}_{2} \mathrm{O}_{2} \rightarrow \text { Compound } \mathrm{I}+\mathrm{H}_{2} \mathrm{O} \\
\text { Compound } \mathrm{I}+\mathrm{NO}_{2}{ }^{-} \rightarrow \text { Compound II }+\mathrm{NO}_{2} \\
\text { Compound II }+\mathrm{NO}_{2}{ }^{-}+2 \mathrm{H}^{+} \rightarrow \text { peroxidase }+\mathrm{NO}_{2}+\mathrm{H}_{2} \mathrm{O}
\end{gathered}
$$

$\mathrm{SCN}^{-}$can react with compound I to suppress the formation of not only $\mathrm{NO}_{2}$ but also DAF-2 radical producing $\mathrm{OSCN}^{-}$(Tenovuo, 1989). Phenolic compounds suppress the formation of $\mathrm{NO}_{2}$ and DAF-2 radicals by reacting with compounds I and II.

Certain bacteria in bacterial fraction produce $\mathrm{O}_{2}^{-}$(Marsh \& Martin, 1999; Tenovuo, 1989). Leukocytes migrated into the oral cavity also produce $\mathrm{O}_{2}^{-}$(Al-Essa et al., 1994; Nakahara et al., 1998; Yamamoto et al., 1991). $\mathrm{O}_{2}^{-}$produced in the oral cavity is scavenged by salivary superoxide dismutase to generate $\mathrm{O}_{2}$ and $\mathrm{H}_{2} \mathrm{O}_{2}$ (Nagler et al., 2002). $\mathrm{H}_{2} \mathrm{O}_{2}$ generated from $\mathrm{O}_{2}{ }^{-}$is used as a substrate of peroxidases. However, $\mathrm{O}_{2}{ }^{-}$can encounter with $\mathrm{NO}$ produced by nitrite-reducing bacteria, resulting in the production of $\mathrm{ONOO}^{-}$in the oral cavity, 


$$
\begin{gathered}
\mathrm{NO}+\mathrm{O}_{2}^{-} \rightarrow \mathrm{ONOO}^{-} \\
\mathrm{ONOO}^{-}+\mathrm{H}^{+} \rightleftarrows \mathrm{ONOOH}(\mathrm{pKa}=6.8) \\
\mathrm{ONOOH} \rightarrow \mathrm{NO}_{2}+\mathrm{OH} \text { radical } \\
\mathrm{ONOOH} \rightarrow \mathrm{NO}_{3}^{-}+\mathrm{H}^{+}
\end{gathered}
$$

$\mathrm{ONOO}^{-}$produced by reaction 9 is protonated to produce $\mathrm{ONOOH}$ around $\mathrm{pH} 7$ (reaction 10). Although $\mathrm{ONOO}^{-}$is unreactive, $\mathrm{ONOOH}$ can transform to $\mathrm{NO}_{2}+\mathrm{OH}$ radical as well as nitrate (Goldstein et al., 2005; Halliwell and Gutteridge, 1999). Therefore, $\mathrm{ONOOH}$ can give oxidative damages to the oral tissues by itself and by producing $\mathrm{NO}_{2}+\mathrm{OH}$ radical. The possibility of $\mathrm{ONOOH}$ formation in the oral cavity is suggested by the result that superoxide dismutase enhanced and inhibited the nitrite-induced formation of DAF-2T and oxidation of APF, respectively, in bacterial fraction (Takahama et al., 2006b, 2007a,b). Superoxide dismutase can prevent the consumption of $\mathrm{NO}$ and the formation of $\mathrm{ONOO}^{-} / \mathrm{ONOOH}$ by reaction 9, leading to the enhancement of DAF-2T formation and the inhibition of APF oxidation. The contribution of $\mathrm{ONOOH}$ in the nitrite-induced oxidation of APF is about $30 \%$ at $\mathrm{pH} 7$ (Takahama et al., 2007a). $\mathrm{ONOO}^{-}$reacts with $\mathrm{CO}_{2}$ producing $\mathrm{ONOOCO}_{2}^{-}$that decomposes to nitrate $+\mathrm{CO}_{2}$ and $\mathrm{NO}_{2}+\mathrm{CO}_{3}{ }^{-}$radical (Goldstein et al., 2005). The concentration of $\mathrm{CO}_{2} / \mathrm{HCO}_{3}{ }^{-}$in saliva $(10-30 \mathrm{mM})$ suggests the reaction of $\mathrm{ONOO}^{-}$with $\mathrm{CO}_{2}$ in the oral cavity (Ferguson, 1989).

DAF-2T formation has also been studied using saliva filtrate. The formation of DAF-2T in the filtrate is much slower than that in bacterial fraction, and is dependent on the concentration of nitrite added (Takahama et al., 2005, 2007a). This result indicates that although $\mathrm{NO}$ is produced by nitrite-reducing bacteria, the formation of DAF-2 radical is inhibited and/or DAF-2 radical is scavenged by certain salivary components. Nitriteinduced oxidative degradation of APF is also much slower in saliva filtrate, implying the presence of scavengers of $\mathrm{NO}_{2}$ and $\mathrm{ONOOH}$ in saliva (Takahama et al., 2007a).

Saliva is collected at $0,1,2,3$, and 4 hours after toothbrushing, and five saliva filtrates are prepared. The rate of nitrite-induced formation of DAF-2T in each filtrate increases with the increase in time after toothbrushing (Takahama et al., 2005). The rate of nitrite-induced DAF-2T formation in bacterial fraction obtained from each saliva filtrate also increases with the increase in time after toothbrushing. These results suggest the gradual growth of nitritereducing bacteria in the oral cavity after toothbrushing.

\subsubsection{Enhancement of RNOS production by decreasing $\mathrm{pH}$}

The $\mathrm{pH}$ of the oral cavity especially dental plaque, where peroxidase and nitrite are present, decreases to below 5 (Bayindir et al., 2005; Crossa et al., 2001; Marsh \& Martin, 1999). Therefore, nitrite-induced transformation of DAF-FM to DAF-FMT has been studied using bacterial fraction in a $\mathrm{pH}$ range from 5.3 to 7.2. It is known that the fluorescent yield of DAFFMT dose not change in the $\mathrm{pH}$ range (Kojima et al., 1999). The DAF-FMT formation was about 10 times faster at $\mathrm{pH} 5.3$ than 7.2, suggesting the faster production of NO under acidic conditions as described in section 3.1.2. The faster formation of DAF-FMT also suggests the faster formation of DFA-FM radical, which can be attributed to the enhanced production of $\mathrm{NO}_{2}$ by peroxidase $/ \mathrm{H}_{2} \mathrm{O}_{2} /$ nitrite systems. Contribution of peroxidase $/ \mathrm{H}_{2} \mathrm{O}_{2} /$ nitrite systems 
to the DAF-FMT formation at $\mathrm{pH} 5.3$ and 7.2 is supported by the result that $\mathrm{SCN}^{-}(<0.2$ $\mathrm{mM}$ ) inhibited the DAF-FMT formation at the $\mathrm{pH}$ values (Takahama et al., 2009a), and the enhanced production of $\mathrm{NO}_{2}$ under acidic conditions is supported by the results that rate of the nitrite-induced oxidation of APF in bacterial fraction is 4-fold faster around $\mathrm{pH} 5$ than 7 (Takahama et al., 2007a). The faster production of $\mathrm{NO}$ and $\mathrm{NO}_{2}$ around $\mathrm{pH} 5$ than 7 can contribute to the much faster formation of DAF-FMT at pH 5.3 than 7.2.

The formation of DAF-FMT is suppressed by various components at $\mathrm{pH} 5.3$ and 7.2. Ascorbic acid $(10 \mu \mathrm{M})(\mathrm{pKa}=4.2,11.6)$ suppressed the DAF-FMT formation more than $90 \%$ at the $\mathrm{pH}$ values, and uric acid $(100 \mu \mathrm{M})(\mathrm{pKa}=5.4$ and 10.3) suppressed the DAF-FMT formation by about $60 \%$ at $\mathrm{pH} 7.2$ but not at $\mathrm{pH} 5.3$ (Takahama et al., 2009a). Phenolic compounds such as quercetin and cathechin $(10 \mu \mathrm{M})$ suppressed the formation of DAF-FMT by 95 and $75 \%$ at $\mathrm{pH} 7.2$ and by 40 and $10 \%$ at pH 5.3, respectively (Takahama et al., 2009a). One of the reasons for the different effects between ascorbic acid and other compounds is the degree of $\mathrm{H}^{+}$-dissociation; more than $80 \%$ of ascorbic acid is present as mono-anion form at $\mathrm{pH} 5$ and 7 . On the other hand, about 40 and $83 \%$ of uric acid are present as mono-anion form at $\mathrm{pH} 5$ and 7, respectively. The dissociation of phenolic $\mathrm{OH}$ groups may increases with the $\mathrm{pH}$ increase from 5 to 7; the pKa values of quercetin are 6.6 and 9.7 (Zenkevich \& Guschina, 2010), and those of chatechin are 8.2 and 9.2 (El-Hady \& El-Maali, 2008).

According to the above mechanism of DAF-FMT formation, ascorbic acid can suppress its formation by scavenging both $\mathrm{NO}_{2}$ and DAF-FM radical and by inhibiting peroxidasecatalyzed production of the above components around $\mathrm{pH} 5$ and 7. Oxidation rate of quercetin by bacterial fraction at $\mathrm{pH} 5.3$ was about $30 \%$ of that at $\mathrm{pH} 7.2$ in the absence of nitrite (Takahama et al., 2009a). This result suggests that the more efficient inhibition of DAF-FMT formation by phenolic compounds at $\mathrm{pH} 7.2$ can be attributed to the more efficient suppression of peroxidase-catalyzed oxidation of nitrite and DAF-FM by quercetin. The greater inhibition of DAF-FMT formation by uric acid at $\mathrm{pH} 7.2$ than 5.3 can also be attributed to more efficient inhibition of peroxidase-catalyzed reactions by uric acid at $\mathrm{pH}$ 7.2 than 5.3. Thus, the differences in pKa values among the above components may contribute to the different inhibitory effects between acidic and neutral conditions.

Nitrite-induced formation of DAF-FMT in bacterial fraction is enhanced by $\mathrm{SCN}^{-}$at $\mathrm{pH} 5.3$ but suppressed at $\mathrm{pH} 7.2$ when $\mathrm{SCN}^{-}$concentration is higher than $1 \mathrm{mM}$ (Takahama et al., 2009a). SCN ${ }^{-}$can react with nitrous acid (Doherty et al., 1997),

$$
\mathrm{HNO}_{2}+\mathrm{SCN}^{-}+\mathrm{H}^{+} \rightleftarrows \mathrm{ONSCN}+\mathrm{H}_{2} \mathrm{O}
$$

This reaction is possible because about $2 \%$ of nitrite is present as nitrous acid at $\mathrm{pH} 5$. ONSCN may contribute to the enhanced formation of DAF-FMT, because $\mathrm{SCN}^{-}$suppresses peroxidase-catalyzed oxidation of nitrite to $\mathrm{NO}_{2}$ as described above. ONSCN can dissociate into $\mathrm{SCN}^{-}$and $\mathrm{NO}^{+}$that is a strong oxidant (Licht et al., 1988). Therefore, $\mathrm{SCN}^{-}$-dependent enhancement of DAF-FMT formation can be attributed to the addition of $\mathrm{NO}^{+}$to DAF-FM or $\mathrm{NO}^{+}$-dependent oxidation of DAF-FM to its radical to react with NO. The latter is supported by the faster NO production under acidic conditions (Takahama et al., 2007a, 2009a).

Nitrite-induced oxidative degradation of APF is about 3 and 5 times faster at pH 5.3 than 7.2 in bacterial fraction and saliva filtrate, respectively. The increased oxidation of APF with the decrease in $\mathrm{pH}$ may be due to the oxidation of APF by salivary peroxidase $/ \mathrm{H}_{2} \mathrm{O}_{2}$ systems, 
$\mathrm{NO}_{2}$ produced by the systems, and $\mathrm{ONOO}^{-} / \mathrm{ONOOH}$. At $\mathrm{pH} 5.3, \mathrm{ONOOH}$ can be produced by the following reaction in addition to reaction 9 .

$$
\mathrm{H}_{2} \mathrm{O}_{2}+\mathrm{HNO}_{2} \rightarrow \mathrm{ONOOH}+\mathrm{H}_{2} \mathrm{O}
$$

As the contributions of $\mathrm{ONOO}^{-} / \mathrm{ONOOH}$ are about 10 and $30 \%$ at $\mathrm{pH} 5.3$ and 7.2, respectively (Takahama et al., 2007a), it is supposed that peroxidase-dependent oxidation of $\mathrm{APF}$ increases with the decrease in $\mathrm{pH}$. Although $\mathrm{SCN}^{-}$is a good inhibitor of salivary peroxidase at pH 5 (Pruitt et al., 1988), $2 \mathrm{mM} \mathrm{SCN}^{-}$enhanced nitrite-induced oxidation of $\mathrm{APF}$ at $\mathrm{pH} 5.3$ in bacterial fraction. The enhancement of APF oxidation by $\mathrm{SCN}^{-}$can be supposed to be due to $\mathrm{NO}^{+}$produced from ONSCN.

The above results suggest that the production of $\mathrm{NO}$ and $\mathrm{NO}_{2}$ increases in the oral cavity with the decrease in $\mathrm{pH}$. The production of ONSCN accompanies the suppression of peroxidase-catalyzed $\mathrm{NO}_{2}$ production by $\mathrm{SCN}^{-}$. The production of $\mathrm{NO}, \mathrm{NO}_{2}$, and $\mathrm{ONSCN}$ is also possible in acidic dental plaque. This is supported by the presence of nitrite, $\mathrm{SCN}^{-}$, and salivary peroxidase in dental plaque (Bayindir et al., 2005; Crossa et al., 2001; Tenovuo, 1989; Tenovuo et al., 1981). The concentration of nitrite in dental plaque is 1.2-2-fold higher than that in saliva (0.05-1 mM) (Bayindir et al., 2005; Crossa et al., 2001). The production of $\mathrm{ONOO}^{-} / \mathrm{ONOOH}$ in acidic dental plaque is possible because superoxide dismutase enhanced and inhibited the formation of DAF-FMT and the oxidative of APF, respectively, in bacterial fraction at $\mathrm{pH} 5.3$ in the presence of nitrite (Takahama et al., 2007a).

\subsection{Nitration}

Following reactions are postulated for main pathways of the nitration of HPA in the oral cavity (Hirota et al., 2005),

$$
\begin{gathered}
\mathrm{H}_{2} \mathrm{O}_{2}+2 \mathrm{HPA} \rightarrow \text { 2HPA radical }+2 \mathrm{H}_{2} \mathrm{O} \text { (catalyzed by peroxidase) } \\
\mathrm{HPA}+\mathrm{NO}_{2} \rightarrow \mathrm{HPA} \text { radical }+\mathrm{NO}_{2}^{-}+\mathrm{H}^{+} \\
\text {HPA radical }+\mathrm{NO}_{2} \rightarrow \mathrm{O}_{2} \mathrm{NHPA}
\end{gathered}
$$

The first step is the oxidation of HPA to its radical, and the second step is the reaction of HPA radical with $\mathrm{NO}_{2}$. Salivary peroxidase catalyzes the nitration of HPA in the presence of both $1 \mathrm{mM}$ nitrite and $0.5 \mathrm{mM} \mathrm{H}_{2} \mathrm{O}_{2}$ at $\mathrm{pH} 5.3$ and 7.2, and rate of the nitration at $\mathrm{pH} 5.3$ is similar to that at $\mathrm{pH} 7.2$ (Hirota et al., 2005). During the nitration, nitrite concentration and HPA concentration decrease. The decrease in nitrite concentration has a broad peak around $\mathrm{pH} 5$, whereas the decrease in HPA concentration has a peak around $\mathrm{pH} 7$. The results suggest that the nitration at $\mathrm{pH} 7.2$ is mainly due to the reaction of $\mathrm{NO}_{2}$ with HPA radicals, both of which are produced by peroxidase-catalyzed oxidation of nitrite and HPA. The contribution of salivary peroxidase on the nitration is supported by $\mathrm{SCN}^{-}$-dependent inhibition of the nitration ( $50 \%$ inhibition, $10 \mu \mathrm{M}$ ) (Takahama et al., 2003a). From the effects of $\mathrm{pH}$ on nitrite and HPA consumption, it is deduced that nitration at $\mathrm{pH} 5.3$ mainly proceeds as followings; oxidation of HPA to its radicals by $\mathrm{NO}_{2}$ and addition of $\mathrm{NO}_{2}$ to the radical. In contrast to the above result, nitration of HPA is about 3 times faster at $\mathrm{pH} 5.3$ than $\mathrm{pH} 7.0$ when the nitration is induced by peroxidase/glucose oxidase/nitrite systems, which 
produce $2 \mu \mathrm{M} \mathrm{H}_{2} \mathrm{O}_{2} / \mathrm{min}$, and the nitration is nearly completely suppressed by $1 \mathrm{mM} \mathrm{SCN}^{-}$ at pH 5.3 (Takahama et al., 2009b). The above two reports imply that peroxidase-dependent $\mathrm{NO}_{2}$ production is faster in acidic than neutral dental plaque in the presence of physiological concentration of $\mathrm{H}_{2} \mathrm{O}_{2}$ in the oral cavity, which is approximately $10 \mu \mathrm{M}$ (Tenovuo, 1989).

Nitrated HPA has been detected in mixed whole saliva from patients of periodontal diseases who are older than 60 years of age (Takahama et al., 2009b). Increased concentrations of nitrite, $\mathrm{HPA}$, and $\mathrm{H}_{2} \mathrm{O}_{2}$ and decreased $\mathrm{pH}$ in the oral cavity may contribute to the formation of nitrated HPA. In fact, the concentrations of nitrite and HPA tend to be higher in individuals with age of 60 -year-old or more. Quercetin $(30 \mu \mathrm{M})$ suppressed nitrite-induced $\mathrm{O}_{2} \mathrm{NHPA}$ formation more than $90 \%$ in bacterial fraction at $\mathrm{pH} 5$ (Hirota et al., 2005) and quercetin can stay in the oral cavity for several hours after ingestion of onion soup (Hirota et al., 2001). Chlorogenic acid, which can also scavenge $\mathrm{NO}_{2}$, stays in the oral cavity for several hours after ingestion of coffee (Takahama et al., 2007b). Therefore, quercetin and chlorogenic acid can function as scavengers of RNOS or electron donors to salivary peroxidase. Flavonoid aglycones and cinnamic acids including chlorogenic acid have been reported to be able to inhibit proliferation of oral cancer cells (Browning et al., 2005; Tanaka et al., 1993; Walle et al., 2005).

\subsection{Oxidation of uric acid}

Nitrite-induced production of $\mathrm{NO}_{2}$ has been estimated by measuring the oxidation of uric acid using saliva filtrate. The rate of uric acid oxidation increases with the decrease in $\mathrm{pH}$ when the $\mathrm{pH}$ is lower than 6 , suggesting that nitrous acid contributes to the oxidation of uric acid (Takahama \& Hirota, 2010). To simulate dental plaque, oxidation of uric acid has been studied using bacterial fraction. $\mathrm{H}_{2} \mathrm{O}_{2}$-induced oxidation of uric acid is enhanced by nitrite, suggesting that $\mathrm{NO}_{2}$ produced by salivary peroxidase $/ \mathrm{H}_{2} \mathrm{O}_{2} /$ nitrite systems contributed to the oxidation of uric acid. $\mathrm{SCN}^{-}(1 \mathrm{mM})$ suppresses the uric acid oxidation by about $75 \%$, confirming that peroxidases participate in the oxidation of uric and that even if ONSCN contribute to the oxidation of uric acid, its contribution is small (Pietraforte et al., 2006; Takahama et al., 2003b; Takahama \& Hirota, 2010)). The contribution of ONOOH formed by reaction 13 cannot be excluded in the oxidation of uric acid by the systems.

\section{Conclusion}

With the decrease in $\mathrm{pH}$ in the oral cavity from 7 to 5 , nitrite-dependent production of not only $\mathrm{NO}, \mathrm{N}_{2} \mathrm{O}_{3}, \mathrm{NO}_{2}$, and $\mathrm{ONOO}^{-} / \mathrm{ONOOH}$ but also ONSCN seems to be enhanced (Figure 1). If the concentration of nitrite in the oral cavity is increased by ingesting nitrate-rich foods, the increased nitrite concentration results in the increase in formation of $\mathrm{NO}, \mathrm{N}_{2} \mathrm{O}_{3}, \mathrm{NO}_{2}$, $\mathrm{ONOO}^{-} / \mathrm{ONOOH}$, and ONSCN under acidic conditions.

Uric acid in saliva can scavenge $\mathrm{NO}_{2}$ and $\mathrm{ONOO}^{-} / \mathrm{ONOOH}$ but not ONSCN. Even if $\mathrm{NO}_{2}$ and $\mathrm{ONOO}^{-} / \mathrm{ONOOH}$ are scavenged by uric acid, the scavenging will not be complete. Thus, if the concentrations of nitrite and $\mathrm{SCN}^{-}$increase accompanying the decrease in $\mathrm{pH}$ of dental plaque, oral tissues adjacent to the plaque will be injured, because $\mathrm{NO}, \mathrm{N}_{2} \mathrm{O}_{3}, \mathrm{NO}_{2}$, $\mathrm{ONOO}^{-} / \mathrm{ONOOH}$, and $\mathrm{NO}^{+}$formed in acidic dental plaque can diffuse to the adjacent tissues. Diffused $\mathrm{NO}$ can be transformed to $\mathrm{N}_{2} \mathrm{O}_{3}$ and/or $\mathrm{ONOO}^{-} / \mathrm{ONOOH}$. Nitrite (0.05-1 
$\mathrm{mM})$ and $\mathrm{SCN}^{-}(0.1-2 \mathrm{mM})$ are always present in the oral cavity (Tenovuo, 1989), therefore it seems to be important to avoid the decrease in $\mathrm{pH}$ in the oral cavity to reduce RNOSinduced injuries of oral tissues.

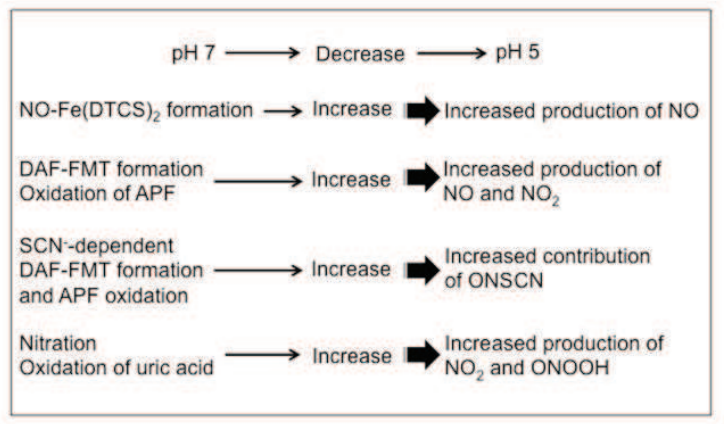

Fig. 1. Increases in RNOS production with the decrease in $\mathrm{pH}$ in the oral cavity

\section{References}

Al-Essa, L., Niwa, M., Kohno, K. \& Tsurumi, K. (1994). A proposal for purification of salivary polymorphonuclear leukocytes by combination of nylon mesh filtration and density-gradient method: a validation by superoxide- and cyclic AMPgenerating responses. Life Science, Vol. 55, pp. PL333-PL338.

Bayindir, Y.Z., Polat, M.F. \& Seven, N. (2005). Nitric oxide concentrations in saliva and dental plaque in relation to caries experience and oral hygiene. Caries Research, Vol. 39, pp. 130-133.

Benjamin, N., O’Driscoll, F., Dougall, H., Duncan, C., Smith, L., Golden, M., McKenzie. H. (1994). Stomach NO. Nature Vol. 368, p. 502.

Browning, A.M., Walle, U.K. \& Walle, T. (2005) Flavonoid glycosides inhibit oral cancer proliferation - role of cellular uptake and hydrolysis to the aglycones. Journal of Pharmacy and Pharmacology, Vol. 57, pp. 1037-1041.

Carossa, S., Pera, P., Doglio, P., Lombardo, S., Colagrande, P., Brussino, L., Rolle, G. \& Bucca, C. (2001). Oral nitric oxide during plaque deposition. Eurropean Journal of Clinical Investigation, Vol. 31, pp. 876-879.

Doel, J.J., Hector, M.P., Amirtham, C.V., Al-Anzan, L.A., Benjamin, N. \& Allaker, R.P. (2004). Protective effect of salivary nitrite and microbial nitrate reductase activity against caries. European Journal of Oral Science, Vol. 111, pp. 424-428.

Doel, J.J., Benjamin, N., Hector, M.P., Rogers, M. \& Allaer, R. P. (2005). Evaluation of bacterial nitrate reduction in the human oral cavity. European Journal of Oral Science, Vol. 113, pp. 14-19.

Doherty, A.M.M., Garley, M.S., Haine, N., and Stedman, G. (1997). Formation of an adduct between thiocyanate ion and nitrosyl thiocyanate. Jornal of Chemical Society, Dalton Transaction, pp. 2163-2166.

Dykhuizen, R.S., Franzer, R., Duncan, C., Smith, C.C., Golden, M., Benjamin, N., Leifert, C. (1996). Antimicrobial effect of acidified nitrite on gut pathogens: Importance of 
dietary nitrate in host defense. Antimicrobial Agents and Chemotherapy. Vol. 40, pp. 1422-1425.

El-Hady, D.A. \& El-Maali, N.A. (2008) Determination of catechin isomers in human plasma subsequent to green tea ingestion using chiral capillary electrophoresis with a highsensitivity cell. Talanta, Vol. 76, pp. 138-145

Espey, M.G., Thomas, D.D., Miranda, K.M., and Wink, D.A. (2002). Focusing of nitric oxide mediated nitrosation and oxidative nitrosylation as a consequence of reaction with superoxide. Proceeding of National Academy of Science U.S.A., Vol. 99, pp. 1112711132.

Ferguson, D.B. (1989). Salivary electrolytes. In: Human Saliva: Clinical Chemistry and Microbiology Vol. 1, Tenovuo, J.O. \& Odont, D., pp. 75-100, CRC Press.

Fujii, S., Yoshimura, T. \& Kamada, H. (1996). Nitric oxide trapping efficiencies of water soluble iron(III) complexes with dithiocarbamate derivatives. Chemical Letters, pp. 785-786.

Goldstein, S., Lind, J. \& Merenyi, G. (2005). Chemistry of peroxynitrites as compared to peroxynitrates. Chemical Review, Vol. 105, pp. 2457-2470.

Halliwell, B. \& Cutteridge, J.M.C. (1999). Free Radical in Biology and Medicine (Third edition), Oxford University Press, 019850045 9, Oxford.

Hirota, S., Nishioka, T., Shimoda, T., Miura, K., Ansai, T. \& Takahama, U. (2001). Quercetin glucosides are hydrolyzed to quercetin in human oral cavity to participate in peroxidase-dependent scavenging of hydrogen peroxide. Food Science and Technology Research, Vol. 7, pp. 239-245.

Hirota, S., Takahama, U., Ly, T.N. \& Yamauchi, R. (2005). Quercetin-dependent inhibition of nitration induced by peroxidase $/ \mathrm{H}_{2} \mathrm{O}_{2}$ /nitrite systems in human saliva and characterization of an oxidation product of quercetin formed during the inhibition. Journal of Agricultural and Food Chemistry, Vol. 53, pp. 3265-3272.

Jourd'heuil, D. (2002). Increased nitric oxide-dependent nitrosylation of 4,5diaminofluorescein by oxidants: implications for the measurement of intracellular nitric oxide. Free Radical Biology and Medicine, Vol. 33, pp. 676-684.

Kojima, H., Nakatsubo, N., Kikuchi, K., Kawahara, S., Kirino, Y., Nagoshi, H., Hirata, Y. \& Nahano, T. (1998). Detection and imaging of nitric oxide with novel fluorescent indicators: diaminofluoreceins. Analytical Chemistry, Vol. 70, pp. 2446-2453.

Kojima, H., Urano, Y., Kikuchi, K., Higuchi, T., Hirata, Y. \& Nagano, T. (1999). Fluorecent indicators for imaging nitric oxide production. Angewandte Chemie International Edition, Vol. 38, pp. 3209-3212.

Licht, W.R., Tannenbaum, S.R. \& Deen, W.M. (1988). Use of ascorbic acid to inhibit nitrosation: kinetic and mass transfer considerations for an in vitro system. Carcinogenesis, Vol. 9, pp. 365-372.

Lingström, P., van Ruyvern F.O.J., van Houte, J. \& Kent, R. (2000). The pH of dental plaque in its relation to early enamel caries and dental plaque flora in humans. Journal of Dental Research, Vol. 79, pp. 770-777.

Marsh, P. \& Martin, M.V. (1999). Oral Microbiology (Fourth edition), Wright, 072361051 , Oxford.

Nagler, R.M., Klein, I., Zarzhevsky, N., Drigues, N. \& Reznick, A.Z. (2002). Characterization of the differentiated antioxidant profile of human saliva. Free Radical Biology and Medicine, Vol. 32, pp. 268-277. 
Nakahara, H., Sato, E.F., Ishisaka, R., Kanno, T., Yoshioka, T., Yasuda, T., Inoue, M. \& Utsumi, K. (1998) Biochemical properties of human oral polymorphonuclear leukocytes. Free Radical Research, Vol. 28, pp. 485-495.

Oldreive, C. \& Rice-Evans, C. (2001). The mechanism for nitration and nitrotyrosine formation in vitro and in vivo: impact of diet. Free Radical Research, Vol. 35, pp. 215231.

Palmerini, C.A., Palombari, R., Perito, S. \& Arienti ,G. (2003). NO synthesis in human saliva. Free Radical Research, Vol. 37, pp. 29-31.

Pannala, A.S., Mani, A.R., Spencer, J.P., Skinner, V., Bruckdorfer, K.R.; Moore, K.P. \& RiceEvans, C.A. (2003). The effect of dietary nitrate on salivary, plasma, and urinary nitrate metabolism in humans. Free Radical Biology and Medicine. Vol. 34, pp. 576584.

Pietraforte, D., Castelli, M., Metere, A., Scorza, G., Samoggia, P., Menditto, A. \& Minetti, M. (2006) Salivary uric acid at the acidic $\mathrm{pH}$ of the stomach is the principal defense against nitrite-derived reactive species: sparing effects of chlorogenic acid and serum albumin. Free Radical Biology and Medicine, Vol. 41, pp. 1753-1763.

Puritt, K.M., Mansson-Rahemtulla, B., Baldone, D.C., \& Rahemtulla, F. (1988) Steady-state kinetics of thiocyanate oxidation catalyzed by human salivary peroxidase. Biochemistry, Vol. 27, pp. 240245.

Setsukinai, K., Urano, Y., Kakinuma, K., Majima, J.J. \& Nagano, T. (2003) Development of novel fluorescent probes that can reliably detect reactive oxygen species and distinguish special species. Journal of Biological Chemistry, Vol. 278, pp. 3170-3175

Takahama, U., Oniki, T. \& Murata, H. (2002). The presence of 4-hydroxyphenylacetic acid in human saliva and the possibility of its nitration by salivary nitrite in the stomach. FEBS Letters, Vol. 518, pp. 116-118.

Takahama, U., Hirota, S., Nishioka, T. \& Oniki, T. (2003a). Human salivary peroxidasecatalyzed oxidation of nitrite and nitration of salivary components 4hydroxyphenylacetic acid and proteins. Archives of Oral Biology, Vol. 48, pp. 679690.

Takahama, U., Yamamoto, A., Hirota, S. \& Oniki, T. (2003b). Quercetin-dependent reduction of salivary nitrite to nitric oxide under acidic conditions and interaction between quercetin and ascorbic acid during the reduction. Journal of Agricultural and Food Chemistry, Vol. 51, pp. 6014-6020.

Takahama, U., Hirota, S. \& Oniki, T. (2005). Production of nitric oxide-derived reactive nitrogen species in human oral cavity and their scavenging by salivary redox components. Free Radical Research, Vol. 39, pp. 737-745.

Takahama, U., Hirota, S. \& Oniki, T. (2006a). Quercetin-dependent scavenging of reactive nitrogen species derived from nitric oxide and nitrite in the human oral cavity: interaction of quercetin with salivary redox components. Archives of Oral Biology, Vol. 51, pp. 629-639.

Takahama, U., Hirota, S. \& Oniki, T. (2006b). Thiocyanate cannot inhibit the formation of reactive nitrogen oxide species in the human oral cavity in the presence of high concentration of nitrite: detection of reactive nitrogen species with 4,5diaminofluorecein, Chemical Research in Toxicology, Vol. 19, pp. 1066-1073.

Takahama, U., Ryu, K., Oniki, T. \& Hirota, S. (2007a). Dual-function of thiocyanate on nitrite-induced formation of reactive nitrogen oxide species in human oral cavity: 
inhibition under neutral and enhancement under acidic conditions. Free Radical Research, Vol. 41, pp. 1289-1300.

Takahama, U., Ryu, K., \& Hirota, S. (2007b). Chlorogenic acid in coffee can prevent the formation of dinitrogen trixode by scavenging nitrogen dioxide generated in the human oral cavity. Journal of Agricultural and Food Chemistry, Vol. 55, PP 9251-9258.

Takahama, U., Hirota, S. \& Oniki, T. (2008a).Detection of nitric oxide and its derivatives in human mixed saliva and acidified saliva. Methods in Enzymology, Vol. 440, pp. 381395.

Takahama, U., Hirota, S. \& Kawagishi, S. (2009a). Effects of pH on nitrite-induced formation of reactive nitrogen oxide species and their scavenging by phenolic antioxidants in human oral cavity. Free Radical Research, Vol. 43, pp. 250-261.

Takahama, U., Imamura, H. \& Hirota, S. (2009b). Nitration of salivary component 4hydroxyphenylacetic acid in the human oral cavity: enhancement of its nitration under acidic conditions. European Journal of Oral Sciences, Vol. 117, pp. 555-562.

Takahama, U. \& Hirota, S. (2010). Nitrogen dioxide-dependent oxidation of uric acid in the human oral cavity under acidic conditions: implications for its occurrence in acidic dental plaque. Chemical Research in Toxicology, Vol. 23, pp. 1067-1075.

Tamme, T., Reinik, M.M., Roasto, M., Juhkam, K., Tenno, T. \& Kiis, A. (2006). Nitrates and nitrites in vegetables and vegetable-based products and their intakes by the Estonian population. Food Additives and Contaminants, Vol. 23, pp. 355-361.

Tanaka, T., Kojima, T., Kawamori, T., Wang, A., Suzuki, M., Okamoto, K. \& Mori, H. (1993). Inhibition of 4-nitroquinoline-1-oxide-induced rat tongue carcinogenesis by the naturally occurring plant phenolics caffeic, ellagic, chlorogenic and ferulic acids. Carcinogenesis, Vol. 14, pp. 1321-1325.

Tenovuo, J. (1989). Nonimmunologlobin defense factors in human saliva. In: Human Saliva: Clinical Chemistry and Microbiology Vol. 2, Tenovuo, J.O. \& Odont, D., pp.55-91, CRC Press.

Tenovuo, J., Mansson-Rahemtulla, B., Pruitt, K.M. \& Arnold, R. (1981) Inhibition of dental plaque acid production by the salivary lactoperoxidase antimicrobial system. Infection and Immunity, Vol. 34, pp. 208-214.

van der Vliet, A., Eiserich, J.P., Halliwell, B. \& Cross, C.E. (1997). Formation of reactive nitrogen species during peroxidase-catalyzed oxidization of nitrite. A potential additional mechanism of nitric oxide-dependent toxicity. Journal of Biological Chemistry, Vol. 272, pp. 7617-7625.

Walle, T., Browning, A.M., Steed, L.L., Reed, S.G. \& Walle, U.K. (2005) Flavonoid glucosides are hydrolyzed and thus activated in the oral cavity in humans. Journal of Nutrition, Vol. 135, pp. 48-52.

Yamamoto, M., Saeki, K. \& Utsumi, K. (1991). Isolation of human salivary polymorphonuclear leukocytes and their stimulation-coupled responses. Archives of Biochemistry and Biophysics, Vol. 289, pp. 76-82.

Zenkevich, I.G. \& Guschina, S.V. (2010) Determination of dissociation constants of species oxidizable in aqueous solution by air oxygen on an example of quercetin. Journal of Analytical Chemistry, Vol. 65, pp. 371-375.

Zetterquist, W., Pedroletti, C., Lundberg, J.O. \& Alving, K. (1999). Salivary contribution to exhaled nitric oxide. European Respiratory Journal, Vol. 13, pp. 327-333. 


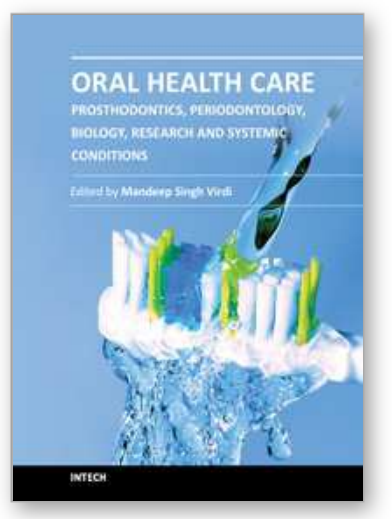

\author{
Oral Health Care - Prosthodontics, Periodontology, Biology, \\ Research and Systemic Conditions \\ Edited by Prof. Mandeep Virdi
}

ISBN 978-953-51-0040-9

Hard cover, 372 pages

Publisher InTech

Published online 29, February, 2012

Published in print edition February, 2012

Geriatric dentistry, or gerodontics, is the branch of dental care dealing with older adults involving the diagnosis, prevention, and treatment of problems associated with normal aging and age-related diseases as part of an interdisciplinary team with other healthcare professionals. Prosthodontics is the dental specialty pertaining to the diagnosis, treatment planning, rehabilitation, and maintenance of the oral function, comfort, appearance, and health of patients with clinical conditions associated with missing or deficient teeth and/or oral and maxillofacial tissues using biocompatible materials. Periodontology, or Periodontics, is the specialty of oral healthcare that concerns supporting structures of teeth, diseases, and conditions that affect them. The supporting tissues are known as the periodontium, which includes the gingiva (gums), alveolar bone, cementum, and the periodontal ligament. Oral biology deals with the microbiota and their interaction within the oral region. Research in oral health and systemic conditions concerns the effect of various systemic conditions on the oral cavity and conversely helps to diagnose various systemic conditions.

\title{
How to reference
}

In order to correctly reference this scholarly work, feel free to copy and paste the following:

Umeo Takahama and Sachiko Hirota (2012). Transformation of Nitrite and Nitric Oxide Produced by Oral Bacteria to Reactive Nitrogen Oxide Species in the Oral Cavity, Oral Health Care - Prosthodontics, Periodontology, Biology, Research and Systemic Conditions, Prof. Mandeep Virdi (Ed.), ISBN: 978-953-510040-9, InTech, Available from: http://www.intechopen.com/books/oral-health-care-prosthodonticsperiodontology-biology-research-and-systemic-conditions/enhanced-formation-of-reactive-nitrogen-oxidespecies-by-proliferation-of-nitrate-and-nitrite-reduci

\section{INTECH}

open science | open minds

\section{InTech Europe}

University Campus STeP Ri

Slavka Krautzeka 83/A

51000 Rijeka, Croatia

Phone: +385 (51) 770447

Fax: +385 (51) 686166

www.intechopen.com

\section{InTech China}

Unit 405, Office Block, Hotel Equatorial Shanghai

No.65, Yan An Road (West), Shanghai, 200040, China

中国上海市延安西路 65 号上海国际贵都大饭店办公楼 405 单元

Phone: +86-21-62489820

Fax: $+86-21-62489821$ 
(C) 2012 The Author(s). Licensee IntechOpen. This is an open access article distributed under the terms of the Creative Commons Attribution 3.0 License, which permits unrestricted use, distribution, and reproduction in any medium, provided the original work is properly cited. 